\title{
The caecilian amphibian Scolecomorphus kirkii Boulenger as prey of the burrowing asp Atractaspis aterrima Günther: trophic relationships of fossorial vertebrates
}

\author{
David J. Gower ${ }^{1, *}$, Jens B. Rasmussen ${ }^{2}$, Simon P. Loader ${ }^{1,3}$ and Mark Wilkinson ${ }^{1}$ \\ ${ }^{1}$ Department of Zoology, The Natural History Museum, London SW7 5BD, U.K., ${ }^{2}$ Zoological Museum, University of Copenhagen, \\ Universitetsparken 15, DK-2100 Copenhagen, Denmark and ${ }^{3}$ University of Glasgow, Institute of Biomedical and Life Sciences, Division of Molecular \\ Genetics, Pontecorvo Building, 56 Dumbarton Rd, Glasgow G11 6NU, U.K
}

\begin{abstract}
A report is given of an adult caecilian, Scolecomorphus kirkii, found in the gut of a specimen of the snake Atractaspis aterrima from the Udzungwa Mountains, Tanzania. Both predator and prey are largely fossorial in soil, and their ecology is poorly known, such that this is the first reported predator of any scolecomorphid caecilian. The caecilian was ingested head first and much of the flesh from the anterior of the specimen had been digested. The prey/predator mass ratio is 0.48 . This value is substantially higher than reported for A. aterrima from West Africa, and refutes the notion that this species feeds only on small prey. Most reported predators of caecilians are snakes, and a brief review is presented.
\end{abstract}

Key words: Africa, Atractaspididae, diet, Gymnophiona, soil, Tanzania

\section{Résumé}

Rapport est donné du cas d'un cécilien adulte, Scolecomorphus kirkii, trouvé dans l'intestin d'un serpent Atractaspis aterrima, dans les Monts Udzungwa, en Tanzanie. Le prédateur et la proie sont en grande partie fouisseurs et on connaît mal leur écologie, à tel point que ceci est le premier cas rapporté de prédateur d'un cécilien scolécomorphe. Le cécilien a été absorbé la tête la première et une grande partie de la chair de l'avant de l'animal avait été digérée. Le rapport de masse proie/prédateur est de 0,48. Ce chiffre est nettement plus élevé que celui rapporté pour $A$. aterrima en Afrique de l'Ouest et contredit l'idée que cette espèce se

*Correspondence: Tel.: +440207942 5080;

Fax: +440207942 5054; E-mail: d.gower@nhm.ac.uk nourrit de petites proies. La plupart des prédateurs des céciliens rapportés sont des serpents et on en présente une brève révision.

\section{Introduction}

Burrowing asps of the genus Atractaspis are venomous, fossorial snakes inhabiting rainforest, woodland, savanna, and semi-desert in mostly tropical Africa and the Arabian peninsula (e.g. Kochva, 2002). Despite their injurious (although rarely fatal, e.g. Spawls \& Branch, 1995) potential for humans, very little is known about the natural history of the genus, perhaps because their fossorial lifestyle makes them relatively elusive (e.g. Akani et al., 2001). Data on the diet of Atractaspis is scant. For example, Cansdale (1961: 68) wrote that 'It is hard to speak about the feeding habits of snakes which are so poorly known, but their diet is known to include skinks, Worm snakes, small rodents and shrews.' Diet and feeding in Atractaspis is of particular interest because of the uncertain phylogenetic position of the Atractaspididae, and an unusual dentition that is highly reduced apart from very long maxillary fangs (e.g. Reinhardt, 1843). This reduced dentition prevents the 'pterygoidwalk' mode of swallowing used by many other higher snakes. Instead, a mechanism convergent with that seen in alethinophidian snakes has evolved in Atractaspis. This is perhaps an adaptation to their fossorial habit (Deufel \& Cundall, 2003).

Caecilian amphibians (order Gymnophiona) are an inadequately understood and relatively understudied component of tropical vertebrate faunas. As with Atractaspis, caecilians are fossorial, elongate and limbless, and their predator-prey relationships are inadequately known. There are few reports of predators of caecilians, and 
apparently none for the endemic African family Scolecomorphidae. Here we add to the meagre knowledge of diet in atractaspidid snakes and the predators of caecilians with a brief report of the discovery of a scolecomorphid caecilian in the gut of an Atractaspis.

\section{Material, methods and results}

The snake specimen is catalogued in the Zoological Museum of the University of Copenhagen, Denmark (ZMUC) as R68320. ZMUC R68320 was collected during 1997-1998 by residents of the Masisiwe area in the Udzungwa Mountains, Tanzania $\left(08^{\circ} 17^{\prime} \mathrm{S}, \quad 35^{\circ} 54^{\prime} \mathrm{E}\right.$, c. $1840 \mathrm{~m}$ a.s.l.). Using the key of Broadley \& Howell (1991), it is identified as Atractaspis aterrima. This identification is based on the single subcaudals and entire anal shield, the short frontal (almost as broad as long), the high number of ventrals (274), and the number of mid-body scale rows (23), a combination of features that is diagnostic for specimens of $A$. aterrima from the Eastern Arc region of East Africa. This species is further distributed westward from Uganda to Senegal. The total length (TL) of ZMUC
$\mathrm{R} 68320$ is $522 \mathrm{~mm}$, and the mass of the preserved specimen minus gut contents is $27.5 \mathrm{~g}$. Other than the caecilian described below, the only other contents in the gut was a short (36 mm, preserved mass $0.5 \mathrm{~g}$ ), autotomized section of the tail of an unidentified lizard. The snake is a female. It is in a fairly good condition, although it was beaten during capture so that its skin is ruptured in three places and the vertebral column is broken in one place.

The caecilian (ZMUC R0277, Fig. 1) removed from the gut of ZMUC R68320 is a mature female, based on examination of its gonads. It has a TL of $356 \mathrm{~mm}$ and preserved mass of $13.2 \mathrm{~g}$. Identification of species of Scolecomorphus is largely determined by colour pattern (Nussbaum, 1985), and ZMUC R0277 is identified as Scolecomorphus kirkii. In addition to its colour pattern, the numbers of annuli (147) and vertebrae (158) are within the known range for females of this species (140-152 and 150-165, respectively; $n=23$, Nussbaum, 1985).

Given its orientation in the snake's gut, the caecilian is interpreted as having been ingested head first. Its anterior end is heavily digested with most of the skin and other, outer soft tissue of the cranium and mandibles having been

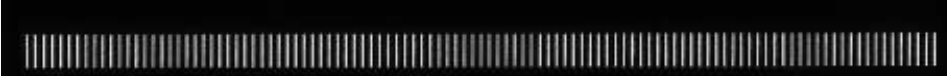

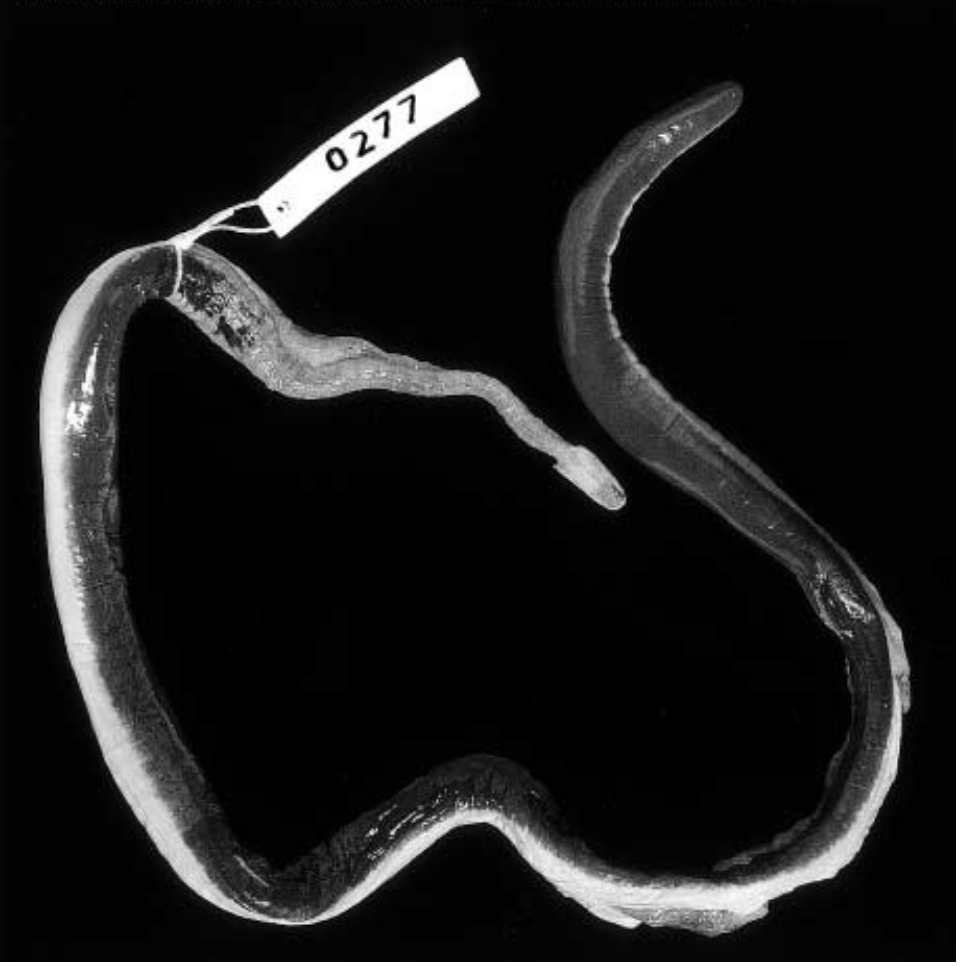

Fig 1 Dorsal view of a partially digested caecilian amphibian, Scolecomorphus kirkii, removed from the gut of a specimen of the atractaspidid snake Atractaspis aterrima from Tanzania. Scale bar in millimetres. 
removed so that many of the bony elements are exposed. The eyes remain in place in the tentacular grooves. The skin is missing from the anterior of the body, up to the level of about the 24th annulus. Much of the flesh is also missing from this region, including the more superficial 'external muscular sheath' (Nussbaum \& Naylor, 1982). Deeper muscle remains attached to the vertebrae so that only a very small amount of bone is directly visible. A similar pattern of loss of flesh from the head was reported by Barbour \& Loveridge (1928) for an individual of the Tanzanian caeciliid Boulengerula boulengeri extracted from the gut of the elapid snake Elapsoidea nigra. The amount of flesh remaining intact on the anterior of ZMUC R0277 increases steadily up to the 24th annulus. From the 24th to about the 60th annulus, the body and skin are in good condition. From about the 60-117th annulus, the body wall is notably flaccid and there are substantial patches where the outer layer of skin is missing. This might be attributable to imperfect preservation, to the fact that the snake was damaged, or perhaps it instead indicates that the caecilian was bitten and possibly envenomated here by the A. aterrima. The remaining length of the specimen, from about the 118th annulus to the posterior terminus, is in good condition with no indication of any external damage. X-ray examination revealed no damage to any of the bones of the cranial, mandibular, or axial skeleton.

\section{Discussion}

Spawls et al. (2002): 439) stated that 'virtually nothing is known' of the natural history of A. aterrima, and this is, to the best of our knowledge, the first report of this genus feeding on caecilians. That Atractaspis feed on other highly fossorial, elongate lower vertebrates, at least occasionally, is demonstrated by reports of scolecophidian snakes (Barbour \& Loveridge, 1928: 137; Loveridge, 1933: 279) and an amphisbaenian squamate (Loveridge, 1951: 202) in the gut of specimens from Uganda and Tanzania. Akani et al. (2001) reported that the gut and faeces contents of three individuals of $A$. aterrima from Nigeria were snakes (including the colubrid Natriciteres sp.) and forest skinks (Panaspis sp.). For at least four sympatric species of Atractaspis, Akani et al. reported an overall statistically significant positive relationship between predator size and prey size, and that 'although the sample size was small', the slopes of this relationship were significantly different among the species studied, with A. aterrima taking the proportionately smallest prey.
The predator mass : prey mass values given by Akani et al. (2001) were largely for fresh specimens, and the predator mass values included gut contents (L. Luiselli, pers. comm.). Assessing an accurate comparable ratio in the present case is problematic because mass was only measured for the preserved predator and prey, and both values will undoubtedly be lower than they were in life the snake has a midventral incision along much of its length, and the caecilian is partly digested. Additionally, this study is based on a minimal sample, and the following, limited interpretation must be treated with care.

Prey/predator mass ratio (MR; equivalent to the weight ratio WR of Greene, 1983) have been calculated from the preserved masses. The greatest WR value for A. aterrima recorded by Akani et al. from their Nigerian sample was about 0.06 (Akani et al.'s Fig. 1). In the present Tanzanian case, $\mathrm{MR}=0.32$ (0.48 if predator mass is recorded minus gut contents), which is almost an order of magnitude greater, and about one and a half times the value of the greatest MR value for any of the species of Atractaspis reported by Akani et al. (2001) (Fig. 1). The MR value reported here for the Tanzanian specimens is, of course, associated with measurement error caveats, but it might be taken to indicate that A. aterrima does not necessarily tend 'to prey upon very small prey' (Akani et al., 2001: 92).

Even including gut contents and allowing for a $10 \%$ decrease in mass upon preservation in alcohol (as reported for lizards by Colbert, 1967), the mass ( $c .70$ to $>118 \mathrm{~g}$ ) of three Nigerian specimens of $A$. aterrima given by Akani et al. (2001) (Fig. 1) is substantially greater than the mass of the Tanzanian specimen under consideration here, despite the latter being longer. This is also true for seven West African A. aterrima in the collections of The Natural History Museum, London (TL 279-645 mm; preserved mass $5.2-48.2 \mathrm{~g}$ ). For ZMUC Tanzanian specimens of A. aterrima, the largest male has a TL of $660 \mathrm{~mm}$ and a preserved mass of $71 \mathrm{~g}(\mathrm{n}=3)$, and the largest female a TL of $670 \mathrm{~mm}$ and of mass $53 \mathrm{~g}(\mathrm{n}=3)$. The two heaviest A. aterrima reported by Akani et al. were females that were gravid, but their $c .70 \mathrm{~g}$ specimen was not (L. Luiselli, pers. comm.), and the apparent discrepancy between the two studies is not fully explained by reduction in mass caused by preservation. The relationship between mass and length in fresh and preserved Atractaspis requires further investigation.

If there is truly a great variation in relative prey size within A. aterrima, then this might be attributable to a 
large number of factors, potentially including geography and the presence of sympatric species of Atractaspis. Simpler hypotheses are also worth considering, and it might be noted that 'feeding both on small and large prey is common for most snakes' (Marques, 1996). Furthermore, it is known that some snakes can change their diet under various circumstances (e.g. de Queiroz et al., 2001), so that the proportionately very small size of the prey taken by the two largest A. aterrima reported by Akani et al. (2001), might conceivably be related to their gravidity. Clearly, more data are needed for a satisfactory assessment of diet in Atractaspis.

As far as we are aware, this is the first report of any predator of the African endemic Scolecomorphidae. In life, S. kirkii have a striking colour pattern comprising a very dark dorsum and a strongly contrasting (Fig. 1), pinkish venter. Nussbaum (1998: 54) has suggested that the bright colouration of some caecilians might be aposematic, associated with possible skin toxins. It might be speculated that the striking colour pattern of $S$. kirkii is, at least in part, an adaptation to avoid predation, but A. aterrima do not seem to be deterred by this and/or any toxins that this caecilian might produce.

Species of Scolecomorphus are known only from Malawi and Tanzania in East Africa, where they inhabit rainforest of the highlands, including the Udzungwa, Uluguru, Usambara and Pare Mountains of the Eastern Arc (Nussbaum, 1985). Caecilians other than Scolecomorphus are known from some of the western part of the range of A. aterrima, but apparently the only report of their predators is of the fossorial, venomous atractaspidid Polemon acanthias preying on the caeciliid Geotrypetes seraphini in Ghana (Cole, 1967).

As with many aspects of the biology of caecilians, knowledge of their predators is inadequate. Taylor (1968: 393) suggested that for terrestrial caecilians 'doubtless snakes and carnivorous birds are the most active predators'. For snakes, this is supported in that they are the taxa in the vast majority of literature reports of caecilian predators. These reports include preying on the caeciliid Caecilia intermedia and an unspecified caecilian by the fossorial/cryptic, nonvenomous colubrid Ninia atrata and the venomous elapid Micrurus ancoralis ancoralis, respectively, in Colombia (Boulenger, 1913); the semi-aquatic typhlonectid Chthonerpeton indistinctum by the aquatic, diurnal aglyphous colubrid Sordellina punctata in Brazil (Procter, 1923); several individuals of the caeciliid B. boulengeri by the mostly nocturnal, fossorial/cryptic and venomous elapid E. nigra in Tanzania (Barbour \& Loveridge, 1928: 182; Jakobsen, 1997: 65); the caeciliid Siphonops annulatus by the largely nocturnal, venomous colubrid Clelia clelia (Sawaya, 1937) and Siphonops sp. by the nocturnal, venomous elapid Micrurus coralinus (Marques \& Sazima, 1997) and the venomous M. decoratus (Marques, 2002) in Brazil; the caeciliid Caecilia gracilis by the fossorial, nonvenomous aniliid Anilius scytale in Surinam (Taylor, 1968: 34; Nussbaum \& Hoogmoed, 1979); the caeciliid Gymnopis multiplicata by the venomous elapid Micrurus multifasciatus hertwigi (Burger, 1997) in Costa Rica; the caeciliids Microcaecilia sp. and Oscaecilia sp. by the venomous elapid Micrurus lemniscatus in Brazilian Amazonia (Martins \& Oliveira, 1998); the ichthyophiid Ichthyophis sp. by the nocturnal, venomous elapid Bungarus candidus (Grossmann \& Schäfer, 2000) and the fossorial, nonvenomous cylindrophiid Cylindrophis ruffus in Thailand (Greene, 1983; Kupfer et al., 2003). Neotropical coral snakes of the venomous elapid genus Micrurus are clearly the most commonly reported snakes preying on caecilians. Roze (1996: 60) reports that among nine species of Micrurus known to prey on caecilians, M. m. mipartitus from Panama and Colombia, and M. bocourti from Ecuador and Peru, are 'known to feed only on caecilians'. Marques \& Sazima (1997) found that although caecilians are a significant prey item of species of Micrurus, their most common prey are amphisbaenian fossorial reptiles.

Some, but not all, of the records of snakes preying on caecilians report the headfirst ingestion of prey. Marques \& Sazima (1997) suggest that instances of tail-first ingestion of fossorial vertebrates by elapid coral snakes are associated with underground feeding. Where reported snake predators are not fossorial or semi-fossorial, they are often nocturnal and/or the caecilian has been found being ingested while moving on the surface (e.g. Burger, 1997; Grossmann \& Schäfer, 2000; Kupfer et al., 2003). However, the sample size is currently very small and more data are required before any firm general conclusions can be drawn.

\section{Acknowledgements}

We thank Harry Greene, Barry Hughes, Luca Luiselli, Colin McCarthy, Garth Underwood, and two anonymous reviewers for helpful information and comments on earlier drafts of the manuscript. Support was provided, in part, by the EU COBICE programme (to DJG, SPL \& MW), a NERC studentship (to SPL) and Leverhulme Trust Grant F/00696/F (to DJG \& MW). 


\section{References}

Akani, G.C., Luiselui, L.M., Angelici, F.M., Corti, C. \& Zuffi, M.A.L. (2001) The case of rainforest stiletto snakes (genus Atractaspis) in southern Nigeria. Evidence of diverging foraging strategies in grossly sympatric snakes with homogenous body architecture. Ethol. Ecol. Evol. 13, 89-94.

Barbour, T. \& Loveridge, A. (1928) A comparative study of the herpetological faunae of the Uluguru and Usambara Mountains, Tanganyika Territory with descriptions of new species. Mem. Museum Comp. Zool. 50, 87-261.

Boulenger, G.A. (1913) On a collection of batrachians and reptiles made by Dr. H. G. F. Spurell, F. Z. S. in the Choco, Colombia. Proc. Zool. Soc. Lond. 1913, 1019-1038.

BroadLEy, D.G. \& HowelL, K.M. (1991) A checklist of the reptiles of Tanzania, with synoptic keys. Syntarsus 1, 1-70.

Burger, R.M. (1997) Predation by two species of Coral Snakes in Limón Province, Costa Rica. Bull. Chicago Herpetol. Soc. 32, 145.

Cansdale, G.S. (1961) West African Snakes. Longman, London.

COLBERT, E.H. (1967) Adaptations for gliding in the lizard Draco. Am. Museum Novitates 2283, 1-20.

Cole, L.R. (1967) The snake Miodon acanthias found with Geotrypetes seraphini (Amphibia: Caeciliidae) as prey. Copeia 1967, 862.

Deufel, A. \& Cundall, D. (2003) Feeding in Atractaspis (Serpentes: Atractaspididae): a study in conflicting functional constraints. Zoology 106, 43-61.

GREENE, H.W. (1983) Dietary correlates of the origin and radiation of snakes. Am. Zoologist 23, 431-441.

Grossmann, W. \& SchäFER, C. (2000) Eine Blindwühle der Gattung Ichthyophis Fitzinger, 1826 als Beute des Malayen-Kraits Bungarus candidus (Linnaeus, 1758). Sauria 22, 45-46.

JaKobsen, A. (1997) A review of some East African members of the genus Elapsoidea Bocage with the description of a new species from Somalia and a key for the genus (Reptilia, Serpentes, Elapidae). Steenstrupia 22, 59-82.

Kochva, E. (2002) Atractaspis (Serpentes, Atractaspididae) the burrowing asp; a multidisciplinary minireview. Bull. Nat. Hist. Museum, Lond. (Zool.) 68, 91-99.

KuPfer, A., Gower, D.J. \& HimstedT, W. (2003) Field observations on the predation of the caecilian amphibian Ichthyophis sp. by the red-tailed pipe snake Cylindrophis ruffus. Amphibia - Reptilia 24, 212-215.

LOVERIDGE, A. (1933) Reports of the scientific results of an expedition to the Southwestern Highlands of Tanganyika Territory. VII Herpetology. Bull. Museum Comp. Zool. 74, 197-416.

LOVERIDGE, A. (1951) On reptiles and amphibians from Tanganyika Territory collected by C.J. Ionides. Bull. Museum Comp. Zool. 106, 175-204.

Maroues, O.A.V. (1996) Sordellina punctata (NCN). Diet. Herpetol. Rev. 27, 147.
Maroues, O.A.V. (2002) Natural history of the coral snake Micrurus decoratus (Elapidae) from the Atlantic Forest in southern Brazil, with comments on possible mimicry. Amphibia - Reptilia 23, 228-232.

Marques, O.A.V. \& SAZIMA, I. (1997) Diet and feeding behavior of the coral snake, Micrurus coralinus, from the Atlantic forest of Brazil. Herpetol. Nat. Hist. 5, 88-91.

Martins, M. \& Oliveira, M.E. (1998) Natural history of snakes in forests of the Manaus region, Central Amazonia, Brazil. Herpetol. Nat. Hist. 6, 78-150.

Nussbaum, R.A. (1985) Systematics of caecilians (Amphibia: Gymnophiona) of the family Scolecomorphidae. Occasional Papers of the Museum of Zoology, University of Michigan 713, $1-49$.

Nussbaum, R.A. (1998) Caecilians. In: Encyclopedia of reptiles and amphibians (Eds H. C. COGGer and R. G. ZweIfel ). Academic Press, San Diego. pp. 52-59.

Nussbaum, R.A. \& Hoogmoed, M.S. (1979) Surinam caecilians, with notes on Rhinatrema bivittatum and the description of a new species of Microcaecilia (Amphibia, Gymnophiona). Zoologische Mededeelingen 54, 217-235.

Nussbaum, R.A. \& NAYLoR, B.G. (1982) Variation in the trunk musculature of caecilians (Amphibia: Gymnophiona). J. Zool. 198, 383-398.

Procter, J.B. (1923) On a new genus and species of colubrine snake from southeast Brazil. Ann. Mag. Nat. Hist. (9) 11, 227230.

De QueIroZ, A., Henke, C. \& Smith, H. M. (2001) Geographic variation and ontogenetic change in the diet of the Mexican Pacific Lowlands Garter Snake, Thamnophis validus. Copeia 2001, 10341042 .

REINHARDT, I.Th. (1843) Beskrivelse af nogle nye slangearter. Videnskabernes Selskabs naturvidenskabelige og mathematiske Afhandlinger 10, 233-279. [Translated by RASMussen, J.B. \& Hughes, B. (1997) Steenstrupia 22, 13-39].

Roze, J.A. (1996) Coral Snakes of the Americas: Biology, Identification, and Venoms. Krieger Publishing Company, Malabar, Florida.

SAWAYA, P. (1937) Die Blindwühle Siphonops annulatus (Mikan) als Nahrung der 'Mussurana'. Pseudoboa cloelia (Daud.). Zoologischer Anzeiger 118, 169-171.

Spawls, S. \& Branch, W. (1995) The Dangerous Snakes of Africa. Blandford, London.

Spawls, S., Howell, K., Drewes, R. \& Ashe, J. (2002) A Field Guide to the Reptiles of East Africa. Academic Press, San Diego.

TAYLOR, E.H. (1968) The Caecilians of the World. University of Kansas Press, Lawrence. 